\title{
Congenital Disorder of Glycosylation Type If
}

National Cancer Institute

\section{Source}

National Cancer Institute. Congenital Disorder of Glycosylation Type If. NCI Thesaurus. Code C126872.

A cong enital disorder of glycosylation sub-type caused by mutation(s) in the MPDU1 gene, encoding mannose-P-dolichol utilization defect 1 protein. 